\title{
Quantification and classification of low back pain severity based on Aberdeen low back pain scale
}

\author{
Kumkum Pandey* and Deepa Vinay \\ \& Technology, Pantnagar -263145(Uttarakhand), INDIA \\ Corresponding author. E-mail: kumkum.pandey.unique@gmail.com \\ Received: March 14, 014; Revised received: February 12, 2015; Accepted: March 10, 2015
}

Department of Family Resource Management, College of Home Science, Govind Ballabh Pant University of Agriculture

\begin{abstract}
Occupational low back pain (LBP) remains the leading safety and health challenge for many industries. The present study was focused to evaluate the physical demands of the manual material handling task in terms of back pain to assess the potential risk of injury. This investigation measures the prevalence of low back pain of rice mill workers in Rudrapur block, District Udhamsingh Nagar, Uttarakhand. Sixty workers, extensively involved in manual material handling $(\mathrm{MMH})$ task (including, loading, unloading, stacking, filling carrying of rice or paddy sack etc.) were investigated for the presence of low back pain and associated personal and workplace risk factors and symptoms. The severity, intensity; frequency, duration and medication of low back pain was assessed utilizing the 'Aberdeen Low Back Pain Scale' developed by Ruta and Garratt (1994) on the basis of scoring in terms of light, moderately light, heavy, very heavy and extremely heavy back pain. The interpretation of scores revealed that $18.33 \%$ respondents were falling under the category of moderately light pain $(\mathrm{M}), 66.66 \%$ respondents were under heavy back pain $(\mathrm{H})$, only $15 \%$ were under the category of very heavy back pain $(\mathrm{V})$, whereas none of the respondents were under the category of light pain (I) and extremely heavy pain (E). It was concluded that there remains an interest in developing integrated models to predict LBP among Rice mill workers using ergonomic and psychosocial factors as well as control strategies to reduce risk of injury.
\end{abstract}

Keywords: Low Back Pain, Manual Material Handling, MSD, Scale

\section{INTRODUCTION}

Low back pain (LBP) is a widely prevalent and complex syndrome of regional pain, often cited as a major cause of disability and inability to work (Deyo and Weinstein, 2001). It is estimated that during the course of their lives 70-85\% of individuals experienced low back pain (Andersson, 1999). The commonest presentation of LBP are acute and sub acute episodes that last up to three months, but chronic back pain lasting more than 3 months ultimately is more disabling and dispiriting because of the physical impediment, it's causes and psychological effects (Ehrlich, 2003). Though several risk factors have been identified (occupational posture, depressive moods, obesity, body height and age), the causes of the onset of low back pain remain obscure and diagnosis difficult to make. In this concern the low back pain is among the top 10 diseases and injuries that account for the highest number of disability -adjusted-life-years (DALYs) worldwide (Mazroa and Mohammad, 2012).

Therefore, it is also common in manual materials handling $(\mathrm{MMH})$ industries, it has been shown that the majority of over-exertion injuries occur as a result of lifting tasks, which have also been identified as one of the leading causes of low back pain (LBP) (NIOSH, 1991).
Considering the cost in man-hours, rehabilitation, and the chance of reoccurrence, prevention of LBP has been a major focus in workplace education and job design (Gundewall et al., 1993; Kim and Chung, 1995; Mooney et al., 1995). From an occupational biomechanics perspective, the load, frequency, and duration of the lift are often assessed in relation to the method (technique) of lifting, raising a number of associated challenges. It has been clearly shown that lifting performance can vary considerably despite using similar lifting methods even when the lifting task is constrained (Hsiang and McGorry, 1997; Albert et al., 1999). Larivie're et al. (2002), for example found no differences in the lifting technique between a chronic low back pain group and control group using a parameter-based approach.

According to Cole and Grimshaw (2003) the incidence of low back pain has continued to increase in modern society, despite the considerable amount of scientific research that has aimed to isolate its exact aetiology. Although low back pain is still largely idiopathic, research has identified over one hundred risk factors for the condition. Of these risk factors, MMH tasks are perhaps the most widely explored within the biomechanical literature, as these tasks have been associated with high mechanical stresses on the lower back. However, 
LBP continues to pose a significant threat to the financial stability and happiness of millions of people worldwide. In addition, a number of functional work capacity assessment tests use lifting as a method for assessment of return to work condition but these tests are not standardized and do not consider the implications of low back loading. Therefore new research attempts in this area are justified and should aim to identify the extent of the association that exists between the known risk factors and the incidence of low back pain.

\section{MATERIALS AND METHODS}

The study was designed as a questionnaire survey with subjects of rice mill of Rudrapur block, district, Udhamsingh Nagar. The study sample consisted of 60 workers who were involved in manual material handling $(\mathrm{MMH})$ task of rice mill. There was exclusion criteria applied. Workers were included in the study if they were considered healthy as operationally defined by them: (1) having no previous history of LBP; or (2) having had LBP in the last 2 years that did not require them to seek medical attention or to change their activities. Subjects were included in the study after their informed consent was given and the study was approved by the Faculty of the KLA rice mill ethical committee. The survey was performed during the regular work period. The schedule consisted of the items describing general demographic and working data (age, education, caste, working hours) and a scale developed by Ruta and Garratt (1994) namely, 'Aberdeen Low Back Pain Scale' to assess the severity of low back pain. It consisted of eighteen questions and was adapted with minor corrections as per the requirement of the study to explore the prevalence of low back pain, its intensity; frequency, duration and medication among the rice mill workers because of prolong lifting and carrying patterns of rice sacs. The final interpretation of Aberdeen Low Back Pain Scale' was done on the basis of scoring and its interpretation in terms of very light, moderately light, heavy, very heavy and extremely heavy back pain. Formula is given below:

BPS (Back pain severity $)=\frac{\text { Sum (Points of all questions answered })}{\text { Sum (Maximum points for questions answered })} \times 100$

\section{RESULTS AND DISCUSSION}

Low back pain and injuries attributed to manual lifting continue to be a leading occupational health and safety issue faced by the industry. Despite efforts to control them, including programs directed at both workers and jobs, work-related back injuries still account for a significant proportion of human suffering and economic cost to any organization. Concurrently this is a leading cause of lost work time, second only to the common cold, and it accounts for up to 240 million lost workdays per year (Center to Protect Workers' Rights, 1997; Kahlil et al., 1993; NIOSH, 1997a; Deyo and Weinstein, 2001). In effort to assess back pain among the workers at rice mill, the "Aberdeen Low Back Pain Scale" was used. Ruta and Garret (1994) from the University of Aberdeen in Scotland discovered and used the "Aberdeen Low Back Pain Scale" to measure outcome in patients with low back pain. It can be used for initial evaluation of the patient and to monitor the effectiveness of any intervention, as the instrument has a good internal consistency, test-retest reliability and construct validity and is valid and reliable too as stated users as well.

Data pertaining to low back pain, assessed on rice mill worker showed that $13.33 \%$ workers were suffering from back or leg pain between, one to 5 days from the last 2 weeks, $23.33 \%$, between $6-10$ days, while $61.66 \%$ suffered from it for more than 10 days. In terms of intake of pain killing tablets results revealed that $26.66 \%$ workers had not taken it at all, however $51.66 \%$ had taken less than 4 tablets, and $23.33 \%$ had taken between 4-8 tablets and none were taken it between 9-12 and more than 12 tablets.

Apart from it, data pertaining to pain made worsted by the various mentioned things showed that $36.66 \%$ workers reported pain by coughing, $28.33 \%$ by sneezing, $75 \%$ by sitting and $86.66 \%$ by standing made the pain worsen, while $100 \%$ felt the pain from bending and that of $88.33 \%$ workers' pain was, worsened by walking. According to Garg and Moore (1992) it is difficult to relate low-back pain to the workplace because it occurs quite often in workers employed in sedentary occupations. However, incidence, severity, and disability are all related to the physical demands of the job. In this regard, jobs involving lifting, lowering, pushing, pulling, carrying, and holding; body movements such as frequent bending, twisting, and sudden movements; and working in bent-over postures appear to have a significant potential for producing low-back pain. A combination of lifting, bending, and twisting appears to be most hazardous. Besides this non-fatal occupational injuries such as sprain, strains, and tears have been primarily linked with work activities such as lifting objects that are too heavy, working in awkward postures for an extended period of time, twisting, bending, falling and slipping (Waters, 2004).

Whereas results related to movements that eases the pain revealed that all the respondents (60) were feeling comfortable by lying and sitting down, similarly 41.66 $\%$ felt comfort by standing and $35 \%$ were of opinion that walking made them comfortable. Further all respondents were feeling pain in the shin or calf and in the foot or ankle of the right leg, while 88.33 in thigh and 36.66 in buttocks.

Whereas in left leg, $66.66 \%$ respondents were feeling pain in buttock, $61.66 \%$ in thigh, $71.66 \%$ in shin or calf and $96.66 \%$ in foot or ankle.

Responses related to loss of feeling in legs showed that $80 \%$ respondents had not reported any loss of feeling in leg, while $20 \%$ were reported for it. Whereas 11.66 $\%$ workers reported weakness and loss of power in hip, 
Table 1. Scoring of back pain severity scores (Ruta and Garret, 1994) (n-60).

\begin{tabular}{|c|c|c|c|c|c|}
\hline $\begin{array}{l}\text { S. } \\
\text { N. }\end{array}$ & Questions & Response & Points & Frequency & $\%$ \\
\hline \multirow{4}{*}{1} & \multirow{5}{*}{$\begin{array}{l}\text { In the past } 2 \text { weeks how many } \\
\text { days did you suffer pain in the } \\
\text { back or leg }(\mathrm{s}) \text { ? }\end{array}$} & None at all & 0 & - & - \\
\hline & & Between 1 and 5 days & 1 & 8 & 13.33 \\
\hline & & Between 6 and 10 days & 2 & 14 & 23.33 \\
\hline & & For more than 10 days & 3 & 37 & 61.66 \\
\hline \multirow{5}{*}{2} & & None at all & 0 & 16 & 26.66 \\
\hline & \multirow{4}{*}{$\begin{array}{l}\text { On the worst day during the } \\
\text { past } 2 \text { weeks how many pain } \\
\text { killing tablets did you take? }\end{array}$} & Less than 4 tablets & 1 & 31 & 51.66 \\
\hline & & Between 4 and 8 tablets & 2 & 14 & 23.33 \\
\hline & & Between 9 and 12 tablets & 3 & - & - \\
\hline & & More than 12 tablets & 4 & - & - \\
\hline \multirow{6}{*}{3} & \multirow{6}{*}{$\begin{array}{l}\text { Is the pain made worse by any } \\
\text { of the following? }\end{array}$} & Coughing & +1 & 22 & 36.66 \\
\hline & & Sneezing & +1 & 17 & 28.33 \\
\hline & & Sitting & +1 & 45 & 75 \\
\hline & & Standing & +1 & 52 & 86.66 \\
\hline & & Bending & +1 & 60 & 100 \\
\hline & & Walking & +1 & 53 & 88.33 \\
\hline \multirow{4}{*}{4} & \multirow{4}{*}{$\begin{array}{l}\text { Do any of the following move- } \\
\text { ments ease the pain? }\end{array}$} & Lying down & +1 & 60 & 100 \\
\hline & & Sitting down & +1 & 60 & 100 \\
\hline & & Standing & +1 & 25 & 41.66 \\
\hline & & Walking & +1 & 21 & 35 \\
\hline \multirow{4}{*}{5} & \multirow{5}{*}{$\begin{array}{l}\text { In your right leg do you have } \\
\text { any pain in the following areas? }\end{array}$} & Pain in buttock & +1 & 22 & 36.66 \\
\hline & & Pain in the thigh & +1 & 53 & 88.33 \\
\hline & & Pain in the shin or calf & +1 & 60 & 100 \\
\hline & & Pain in the foot or ankle & +1 & 60 & 100 \\
\hline \multirow{4}{*}{6} & & Pain in buttock & +1 & 40 & 66.66 \\
\hline & \multirow{3}{*}{$\begin{array}{l}\text { In your left leg do you have any } \\
\text { pain in the following areas? }\end{array}$} & Pain in the thigh & +1 & 37 & 61.66 \\
\hline & & Pain in the shin or calf & +1 & 43 & 71.66 \\
\hline & & Pain in the foot or ankle & +1 & 58 & 96.66 \\
\hline \multirow{3}{*}{7} & \multirow{3}{*}{$\begin{array}{l}\text { Do you have any loss of feeling } \\
\text { in your legs? }\end{array}$} & No & 0 & 48 & 80 \\
\hline & & Yes just one leg & 1 & - & - \\
\hline & & Yes both legs & 2 & 12 & 20 \\
\hline \multirow{4}{*}{8} & \multirow{4}{*}{$\begin{array}{l}\text { In your right leg do you have } \\
\text { any weakness or loss of power } \\
\text { in the following areas? }\end{array}$} & Hip & +1 & 7 & 11.66 \\
\hline & & Knee & +1 & 37 & 61.66 \\
\hline & & Ankle & +1 & 41 & 68.33 \\
\hline & & Foot & +1 & 46 & 76.66 \\
\hline \multirow{4}{*}{9} & \multirow{4}{*}{$\begin{array}{l}\text { In your left leg do you have any } \\
\text { weakness or loss of power in } \\
\text { the following areas? }\end{array}$} & Hip & +1 & 1 & 8.333 \\
\hline & & Knee & +1 & 41 & 68.33 \\
\hline & & Ankle & +1 & 46 & 76.66 \\
\hline & & Foot & +1 & 41 & 68.33 \\
\hline \multirow{5}{*}{10} & & I could touch the floor. & 1 & 60 & 100 \\
\hline & If you were to try and bend & $\begin{array}{l}\text { I could touch my ankles with } \\
\text { the tips of my fingers. }\end{array}$ & 2 & - & - \\
\hline & $\begin{array}{l}\text { forward without bending your } \\
\text { knees how far down to you }\end{array}$ & $\begin{array}{l}\text { I could touch my ankles with } \\
\text { the tips of my fingers. }\end{array}$ & 3 & - & - \\
\hline & $\begin{array}{l}\text { think you could bend before the } \\
\text { pain stopped you? }\end{array}$ & $\begin{array}{l}\text { I could touch my mid thighs } \\
\text { with the tips of my fingers. }\end{array}$ & 4 & - & - \\
\hline & & I could not bend forward at all. & 5 & - & - \\
\hline & & Not affected at all. & 1 & 30 & 50 \\
\hline & On the worst night during the & $\begin{array}{l}\text { I didn't lose any sleep but } \\
\text { needed tablets. }\end{array}$ & 2 & 16 & 26.66 \\
\hline 11 & last week how badly was your & It prevented me from sleeping & 3 & 5 & 8.33 \\
\hline & sleep affected by the pain? & I only had 2-4 hours of sleep. & 4 & 9 & 15 \\
\hline & & $\begin{array}{l}\text { I had less than } 2 \text { hours of } \\
\text { sleep. }\end{array}$ & 5 & - & - \\
\hline
\end{tabular}


Table 1. Contd.

\begin{tabular}{|c|c|c|c|c|c|}
\hline \multirow{5}{*}{12} & \multirow{5}{*}{$\begin{array}{l}\text { On the worst day during the } \\
\text { last } 2 \text { weeks did the pain in- } \\
\text { terfere with your ability to sit } \\
\text { down? }\end{array}$} & $\begin{array}{l}\text { I was able to sit in any chair as long } \\
\text { as I liked }\end{array}$ & 0 & 8 & 13.33 \\
\hline & & $\begin{array}{l}\text { I could only sit in my favourite chair } \\
\text { as long as I liked }\end{array}$ & 1 & 7 & 11.66 \\
\hline & & $\begin{array}{l}\text { Pain prevented me from sitting more } \\
\text { than } 1 \text { hour }\end{array}$ & 2 & 15 & 25 \\
\hline & & $\begin{array}{l}\text { Pain prevented me from sitting more } \\
\text { than } 30 \text { minutes }\end{array}$ & 3 & 22 & 36.66 \\
\hline & & $\begin{array}{l}\text { Pain prevented me from sitting more } \\
\text { than } 15 \text { minutes }\end{array}$ & 4 & 8 & 13.33 \\
\hline \multirow{7}{*}{13} & \multirow{7}{*}{$\begin{array}{l}\text { On the worst day during the } \\
\text { last } 2 \text { weeks did the pain in- } \\
\text { terfere with your ability to } \\
\text { stand? }\end{array}$} & Pain prevented me from sitting & 5 & - & - \\
\hline & & $\begin{array}{l}\text { I could stand as long as I wanted } \\
\text { without extra pain. }\end{array}$ & 0 & 4 & 6.66 \\
\hline & & $\begin{array}{l}\text { I could stand as long as I wanted but } \\
\text { it gave me extra pain }\end{array}$ & 1 & 12 & 20 \\
\hline & & $\begin{array}{l}\text { Pain prevented me from standing } \\
\text { more than } 1 \text { hour }\end{array}$ & 2 & 16 & 26.66 \\
\hline & & $\begin{array}{l}\text { Pain prevented me from standing } \\
\text { more than } 30 \text { minutes }\end{array}$ & 3 & 20 & 33.33 \\
\hline & & $\begin{array}{l}\text { Pain prevented me from standing } \\
\text { more than } 15 \text { minutes }\end{array}$ & 4 & 8 & 13.33 \\
\hline & & $\begin{array}{l}\text { Pain prevented me from standing at } \\
\text { all }\end{array}$ & 5 & - & \\
\hline \multirow{6}{*}{14} & \multirow{6}{*}{$\begin{array}{l}\text { On the worst day during the } \\
\text { last } 2 \text { weeks did the pain in- } \\
\text { terfere with your ability to } \\
\text { walk? }\end{array}$} & $\begin{array}{l}\text { Pain did not prevent me walking any } \\
\text { distance }\end{array}$ & 0 & 9 & 15 \\
\hline & & $\begin{array}{l}\text { Pain prevented me walking more } \\
\text { than } 1 \text { hour }\end{array}$ & 1 & 24 & 40 \\
\hline & & $\begin{array}{l}\text { Pain prevented me from walking } \\
\text { more than } 30 \text { minutes hour }\end{array}$ & 2 & 16 & 26.66 \\
\hline & & $\begin{array}{l}\text { Pain prevented me from walking } \\
\text { more than } 15 \text { minutes }\end{array}$ & 3 & 11 & 18.33 \\
\hline & & I can walk but less than $1 / 4$ & 4 & - & \\
\hline & & I was unable to walk at all & 5 & - & \\
\hline \multirow{5}{*}{15} & \multirow{5}{*}{$\begin{array}{l}\text { In the last } 2 \text { weeks did the } \\
\text { pain prevent you from carry- } \\
\text { ing out your work/ housework } \\
\text { and other daily activities? }\end{array}$} & No not at all & 0 & 18 & 30 \\
\hline & & $\begin{array}{l}\text { I could continue with my work suf- } \\
\text { fered }\end{array}$ & 1 & 36 & 60 \\
\hline & & Yes for one day & 2 & 4 & 6.66 \\
\hline & & Yes for 2-6 days & 3 & 2 & 3.33 \\
\hline & & Yes for 7 days or more & 4 & - & \\
\hline \multirow{4}{*}{16} & \multirow{5}{*}{$\begin{array}{l}\text { In the last } 2 \text { weeks for how } \\
\text { many days have you had to } \\
\text { stay in bed because of the } \\
\text { pain? }\end{array}$} & None at all & 0 & 52 & 86.66 \\
\hline & & Between 1 and 5 days & 1 & 6 & 10 \\
\hline & & Between 6 and 10 days & 2 & 2 & 3.33 \\
\hline & & For more than 10 days & 3 & - & - \\
\hline \multirow{5}{*}{17} & & Not affected by the pain & 0 & - & - \\
\hline & \multirow{4}{*}{$\begin{array}{l}\text { In the last } 2 \text { weeks has your } \\
\text { sex life been affected by your } \\
\text { pain? }\end{array}$} & Mildly affected by the pain & 1 & - & - \\
\hline & & Moderately affected by the pain & 2 & - & - \\
\hline & & Pain prevents any sex life at all & 3 & - & - \\
\hline & & Does not apply & 4 & 60 & 100 \\
\hline \multirow{6}{*}{18} & \multirow{6}{*}{$\begin{array}{l}\text { In the last } 2 \text { weeks have your } \\
\text { leisure activities been af- } \\
\text { fected by your pain? }\end{array}$} & Not affected by the pain & 1 & 11 & 18.33 \\
\hline & & Mildly affected by the pain & 2 & 9 & 15 \\
\hline & & Moderately affected by the pain & 3 & 34 & 56.66 \\
\hline & & Severely affected by the pain & 4 & 6 & 10 \\
\hline & & Pain prevents any social life at all & 5 & - & - \\
\hline & & None at all & 0 & - & - \\
\hline
\end{tabular}

$61.66 \%$ in knee, $68.33 \%$ in ankle and $76.66 \%$ in foot. All the respondents reported that they can touch the floor with their finger and none of the respondents were in other categories. Furthermore responses 


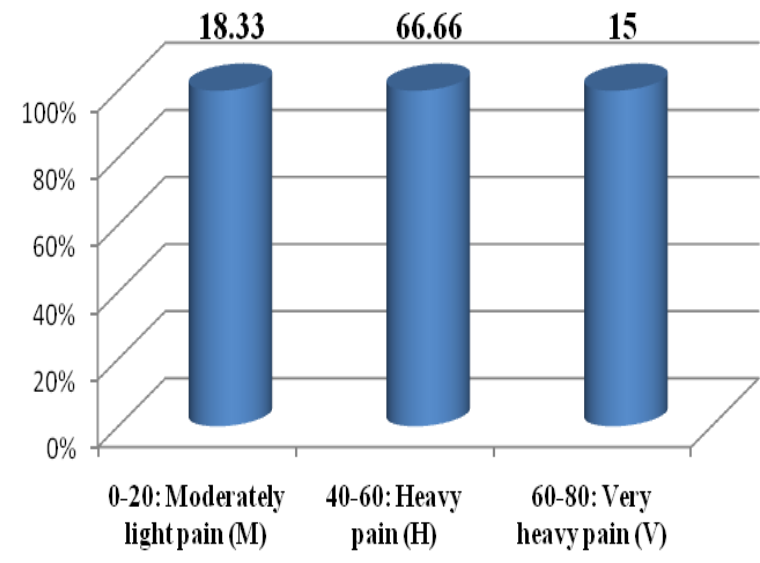

Fig. 1. Low back pain severity score.

regarding sleeping disturbances $40 \%$ respondents revealed that their sleep was not affected at all during night from the last week in spite of reported pain, while $36.66 \%$ did not lose sleep but needed tablets for comfortable sleep, $8.33 \%$ respondents sleep was prevented from pain and only $15 \%$ were had 2-4 hours of sleep.

Similarly in a study Marin et al. (2006) reported a significant relationship between pain and sleep $(\mathrm{P}<0.0005)$ with a $55 \%$ increase in the proportion of subjects reporting restless/light sleep after pain onset. There was no corresponding increase in the sleeping medication used in the low back pain patients.

When the responses recorded about pain interference with ability to sit down from the last two week, it was found that $13.33 \%$ respondents were able to sit on any chair as long as they liked, $11.66 \%$ were able to sit on their favourite chair as long as they liked, $25 \%$ respondents were not able to sit on chair more than one hour because of pain and $36.66 \%$ respondents were prevented from sitting more than 30 minutes.

While responses regarding interference with ability to stand revealed that $6.66 \%$ respondents were able to stand as long as possible without any extra pain, $20 \%$ were able to stand as long as possible but with extra pain, $26.66 \%$ revealed that pain prevented them to stand more than 1 hour and $33.33 \%$ were prevented to stand more than 15 minutes.

Data pertaining to ability to walk showed that $15 \%$ respondents reported that pain did not prevent them to walk an distance, $40 \%$ were prevented to walking more than 1 hours, $26.66 \%$ were prevented to walk more than 30 minutes and remaining $18.33 \%$ were prevented to walk more than 15 minutes because of pain during last 2 weeks. Results related to hurdles in work or in daily activity due to pain revealed that $30 \%$ respondents were not affected at all, $60 \%$ were able to carry out, with their work suffered, $6.66 \%$ respondents reported that their work suffered for one day, $3.33 \%$ workers daily activity or work suffered for 2-6 days and none of the respondents were suffered more than seven days.

It was found that $86.66 \%$ workers were not stayed in bed at all because of pain in body, $10 \%$ were stayed in bed for 1-5 days, 3.33\% were stayed in bed for 6-10 days and none of the respondents were stayed in bed more than 10 days from the last 2 week. All the respondents were reported that pain didn't any effect on their sex life because they were not living with their spouse, so that this question was not found to be applicable for them. While results related to effect on leisure activities revealed that $18.33 \%$ workers leisure activities were not affected by pain from the last 2 weeks, $15 \%$ reported that it was mildly affected, $56.66 \%$ said it was moderately affected, only $10 \%$ revealed it as moderately affected and none of the respondents were found under the category of social life and none at all. In a study Bakker et al. (2009) reviewed and critically evaluated the past literature for spinal mechanical load as a risk factor for low back pain (LBP) and found strong evidences that leisure time sport or exercises, sitting, and prolonged standing/walking are not associated with LBP. Evidence for associations in leisure time activities (e.g., do-it -yourself home repair, gardening), whole-body vibration, nursing tasks, heavy physical work, and working with ones trunk in a bent and/or twisted position and LBP was conflicting. They did not find an association between sleeping or sporting on a professional level and LBP.

Scoring and interpretation of Aberdeen low back pain scale: In the present investigation the "Aberdeen Low- Back-Pain Scale" was administered to calculate its scores to test the severity of back pain. The scale was adapted with minor changes as for the requirement of the study and every question in the instrument was provided with a number of possible response carrying weighted points. The questions were administered by the researcher and the back pain severity scores were calculated.

The interpretation of the calculated back pain severity scores were done on the basis of the above table. Interpretation of scores revealed that $18.33 \%$ respondents were falling under the category of moderately light pain $(\mathrm{M}), 66.66 \%$ respondents were comes under heavy back pain $(\mathrm{H})$, only $15 \%$ were lies under the category of very heavy back pain $(\mathrm{V})$, whereas none of the respondents were falling under the category of light pain (1) and extremely heavy pain (E).

\section{Conclusion}

It was concluded that the forces and risks experienced daily in rice mill activities are significant and need to be addressed. This investigation has pioneered ergonomic research in rice mills and the benefits of such research can be achieved through the development of control strategies to reduce workloads from their present levels thereby reducing risk of LBP in workers. The present study establishes new ground for understanding mill work, asking questions, and suggesting improved methodologies for additional research. It is hoped that more can be learned about multi-factorial nature of LBP and its influences on MMH work in industries. 
There remains an interest in developing integrated models to predict LBP among mill workers using ergonomic and psychosocial factors as well as control strategies to reduce risk in injury.

\section{REFERENCES}

Albert, W.J., Stevenson, J.M. and Costigan, P.A. (1999). Quantification of lifting technique in a manual materials handling plant. In: Lee, G.C.G. (Ed.), Advances in Occupational Ergonomics and Safety, Vol. 3. IOS Press Inc., Virginia, pp. 73-79.

Andersson, G.B.J. (1999). Epidemiological features of chronic low-back pain. Lancet, (354): 581-5.

Bakker, E.W., Verhagen, A.P., Van, T.E., Lucas, C. and Koes, B.W. (2009). Spinal mechanical load as a risk factor for low back pain: a systematic review of prospective cohort studies. Journal of Spine 34(8): 281-93.

Cole, M.H., Grimshaw, P.N. (2003). Low back pain and lifting: a review of epidemiology and aetiology. Work, 21(2):173-84.

Deyo, R.A., Weinstein, J.N. (2001). Primary care-Low back pain. N Engl J Med, (344): 363-70.

Ehrlich, G.E. (2003). Low back pain. Bulletin of the World Health Organization, ( 81): 671-6.

Garg, A. and Moore, J.S. (1992). Epidemiology of low-back pain in industry. Occupational Medicine , 7(4):593-608.

Gundewall, B., Liljeqvist, M., and Hansson, T., (1993). Primary prevention of back symptoms and absence from work: a prospective randomized study among hospital employees. Spine, 18: 587-594.

Hsiang, S.M. and McGorry, R.W., (1997). Three different lifting strategies for controlling the motion patterns of the external load. Ergonomics, 40: 928-939.

Kahlil, T.M., Abdel-Moty, E.M., Rosomoff, R.S., Rosomoff, H.L. 1993. Ergonomics in Back Pain. NY, NY: Van
Nostrand Reinhold.

Kim, S.H. and Chung, M.K. (1995). Effects of posture, weight and frequency on trunk muscular activity and fatigue during repetitive lifting tasks. Ergonomics, 38: $853-863$

Larivie re, C., Gagnon, D. And Loisel, P. (2002). A biomechanical comparison of lifting techniques between subjects with and without chronic low back pain during freestyle lifting and lowering tasks. Clin. Biomech, 17: 89-98.

Marin, M., Cyhan, T.R., Miklos, B.S.N and Wendy, M.D. (2006). Sleep Disturbance in Patients With Chronic Low Back Pain. American Journal of Physical Medicine \& Rehabilitation, 85(5): 430-435.

Mazroa, A. and Mohammad, A. (2012) Years lived with disability (YLDs) for 1160 sequelae of 289 diseases and injuries 1990-2010: a systematic analysis for the Global Burden of Disease Study 2010. Lancet, 380 (9859) :2163-96.

Mooney, V., Kron, M., Rummerfield, P. and Holmes, B., (1995). The effect of workplace based strengthening on low back injury rates: a case study in the strip mining industry. J. Occup. Rehabil. 5: 157-167.।

National Institute for Occupational Safety and Health. 1997a. Musculoskeletal disorders and workplace factors. Publication No. 97-141. Cincinnati, OH: U.S. Department of Health and Human Services.

National Institute of Occupational Safety and Health (1991). Scientific Support Documentation for the Revised 1991 NIOSH Lifting Equation. National Institute of Occupational Safety and health, PB91-2262274.

Ruta, D.A. and Garratt, A.M. (1994). Developing a valid and reliable measure of health outcomes for patienst with low back pain. Spine, 19: 1887-1896.

Waters, T. (2004). National efforts to identify research issues related to prevention of work-related musculoskeletal disorders. Journal of Electromyography and Kinesiology, 14(1):7-12 